\title{
Influence of Macro-Environmental Climatic Factors on Distribution and Productivity of Freshwater Algae
}

\author{
*Sophia Barinova \\ Institute of Evolution, University of Haifa, Israel
}

Submission: July 28, 2017; Published: August 08, 2017

*Corresponding author: Sophia Barinova, Institute of Evolution, University of Haifa, Mount Carmel, 199 Abba Khoushi Ave., Haifa 3498838, Israel, Tel: +972-48249799; Email: sophia@evo.haifa.ac.il

\begin{abstract}
Paper represented the new approach to analysis of the global environmental factors - temperature and solar radiation that influenced the algal community species richness, abundance and biomass. Correlation of algal bloom in the continental freshwater reservoirs in Far East and Pacific El Niño temperature phenomenon was revealed. Our analysis demonstrates the close relationship between the global temperature and world ocean level parameters with such an independent global parameter as the rotation and shape of the planetary geoid. The phytoplankton in the large rivers of the Northeastern Eurasia was analyzed over the latitude distribution. It was found that environmental variables in the latitude about 62 degree are represent the critical value of air temperature that annual averaged about - $12 \mathrm{C}$ and solar irradiation of about $1100 \mathrm{kWh} \mathrm{m} \mathrm{m}^{2}$. Algal communities in habitat below 62 degree of northern latitude have trend of increasing the role of diatoms whereas cyanobacteria, green, and chrysophyte algae are replaced of diatoms in the northern communities. It was to conclude that algal community structure is defined by macroclimatic factors and can be used for the assessment of global environmental variables change.
\end{abstract}

Keywords: Algae; Phytoplankton; Large Rivers; Solar energy; Global temperature; Eurasia

\section{Introduction}

The major source of organic biomass production is based on the global photosynthetic process in which the algae are important primary producers. Protein synthesis is made by the chlorophyll mechanism on the base of trophic elements in the water habitats as well as solar radiation. Algae as basic level of aquatic ecosystem trophic pyramid are defined all higher levels organisms' production [1]. The basic macro variables that support of photosynthetic activity are the sunlight and temperature. However, the same factor is the global and defined the life and evolution. It is difficult to compare the global temperature fluctuation and algal communities development because the data are or not enough, or have incomparable scale.

One of the easy measured global parameter is the length of day (LOD) that defined solar radiation rate [2]. The rate of solar radiation is distributed over the Earth surface unevenly (Figure 1) [3]. The global temperature is defined the photosynthetic mechanism activity and also distributed over the Earth surface unevenly (Figure 2) [4]. Both these important variables are defined the life distribution and diversity over the Earth surface that help to revealed the biomes system (Figure 3) [5].
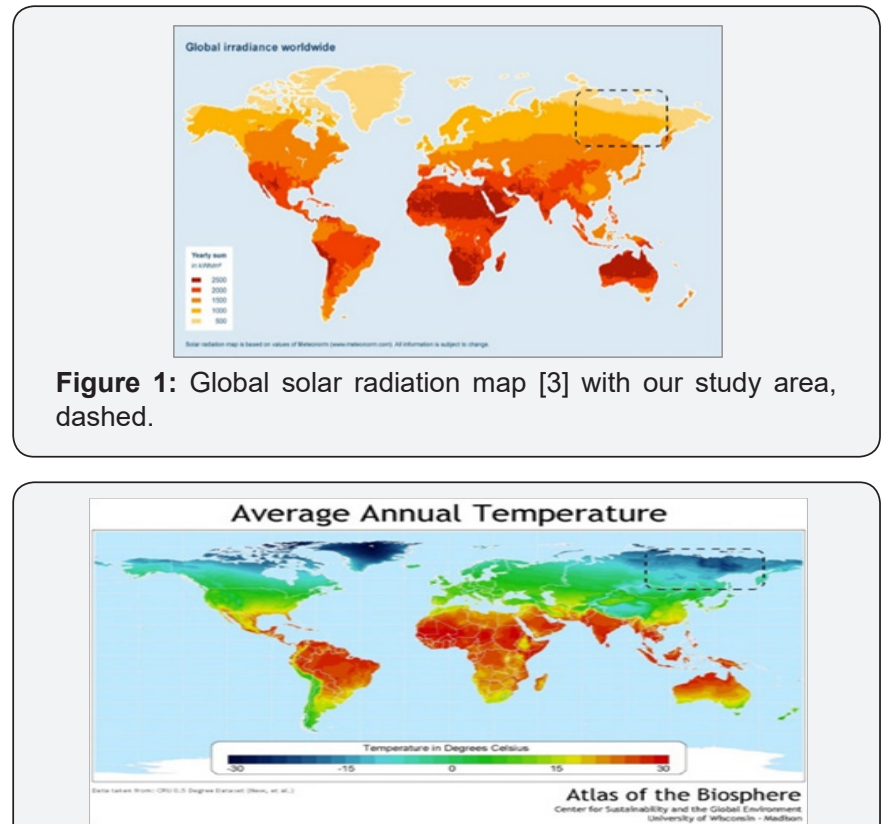

Figure 2: Global average annual temperature map [4] with our study area, dashed. 


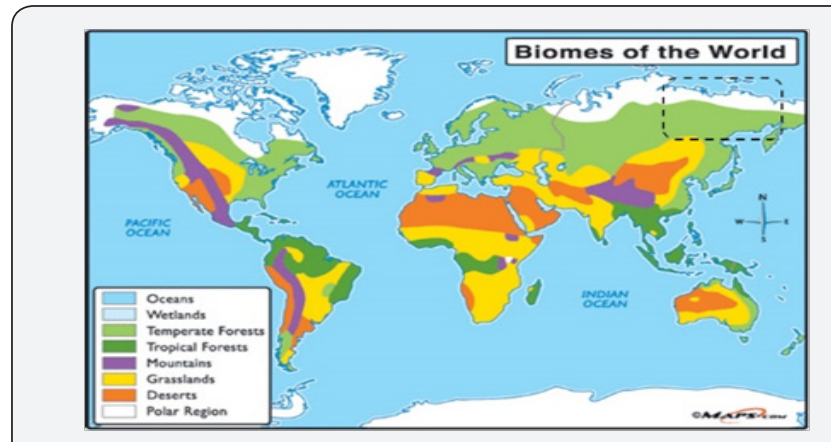

Figure 3: Global diversity distribution as Biomes of the World map [5] with our study area, dashed.

\section{Preliminary scientific research}

Both, solar radiation and water temperature are closely related but the ocean water surface temperature has some special fluctuation named El Niño with about four-year periodicity. This phenomenon was revealed in the Pacific surface and monitor of about hundred years. The opposite phenomenon is called La Niña. Delta of both was calculated by us [2] and is represented in Figure 4. The annual global temperature anomalies, $\Delta \mathrm{T}[6]$ show a definite ascending tendency since 1978 (global warming of the popular greenhouse model), but actually reaching a high plateau with minor fluctuations in 1998-2017 (Figure 4).

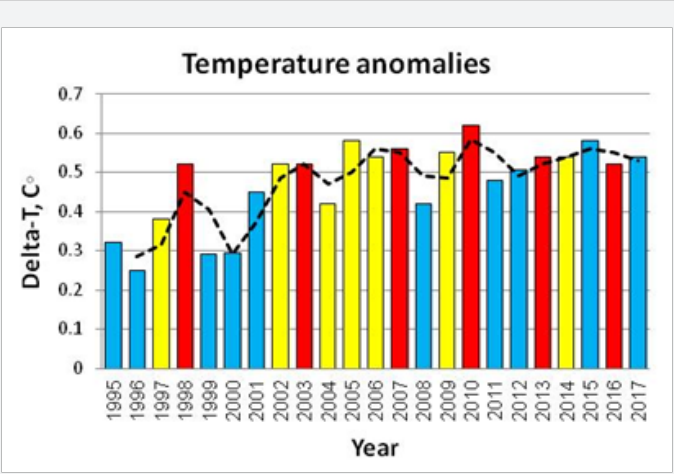

Figure 4: Annual global temperature dynamics; El Niño years moderate to strong (red), La Niña years (blue), transitional years yellow, data from $[6,8,9]$.

The warmest years are marked by red that the same as El Niño years. It is Pacific water temperature, why it important for continental algal communities? Our investigation of algal seasonality development in the Far East water reservoir let us to compare the El Niño years with algal bloom in reservoirs. So, in our experience we revealed that the Artyomovsk Reservoir which placed about $20 \mathrm{~km}$ from the sea was bloomed in years 1983 [7] and later (personal communication) in 1998, 2003 and 2010. The same blooms periods were in the close to sea reservoirs Bogatinskoye, Pionerskoye and other Primorsky district lakes and reservoirs with lag period about few days. In comparison with the red columns of El Niño years can be seen that it is the same. So, it let us to conclude that Pacific temperature is impacted algal bloom of the continental water bodies and therefore can be included to the drinking water quality source management.

As we can see, the ocean is very important thing in the life evolution and its level fluctuation is one of the evidence of the global environment state. The generalized global sea level curve is fluctuated in range about $250 \mathrm{~m}$ and divisible into two major peaks [10]. Because the present day sea level is the lowest for more than 500 myr of the plotted sea level change, the highs and lows of the generalized sea level curve are arbitrary, with ill-defined turning points. For more objective evaluation of sea-level trends, we re-plotted sea levels with 1 myr interval (Figure 5). Standard deviation line of the plot approximates the statistical normal sea level for 542 myr. Sea level rises and falls can be objectively assessed against this level.

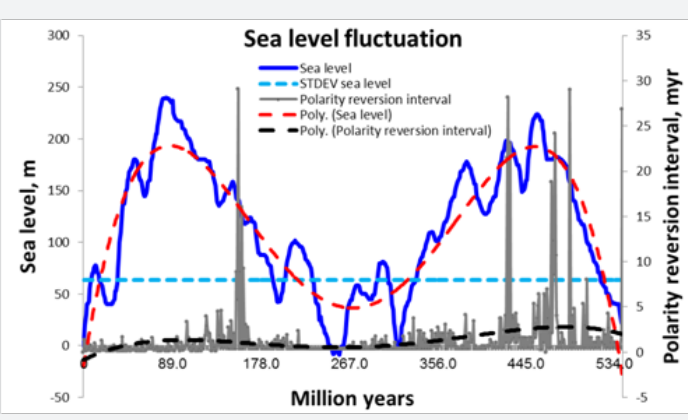

Figure 5: Curves and polynomial trend lines of sea level (data after [11]) and geomagnetic polarity intervals (data after [12]) over 534 myr

The chronological correlation of sea level and geomagnetic polarity is revealed by polynomial trend lines (Figure 5) and the metric congruence of the first and second order cycles. The turning points of both trends coincide and thus reflect natural periodicity of geochronological scale. So, this phenomenon is not only proof of the global warming theory insolvency but also give us evidence for the algal community data mining for the ecological analysis of the community response to the global parameters fluctuation.

\section{Results}

As an example of this scale analysis, we choose the North-Eastern Eurasian large rivers [13]. Figure 6 shows the investigated area with the river channels marked by green. The same area is marked by dashed rectangle in the global maps of Figures 1-3. This area is very large and placed in the northern part of continent with lowest solar radiation and temperatures that defined Boreal and Arctic Biomes of diversity. The gradient of solar radiation for the aquatic ecosystem can be defined as the average ice-free days. Can be seen that the temperature and average ice-free days for the studied rivers were fluctuated synchronously as reflect the distribution trend lines (Figure 7). That means that both global related parameters can define the algal communities' development in the studied rivers. 

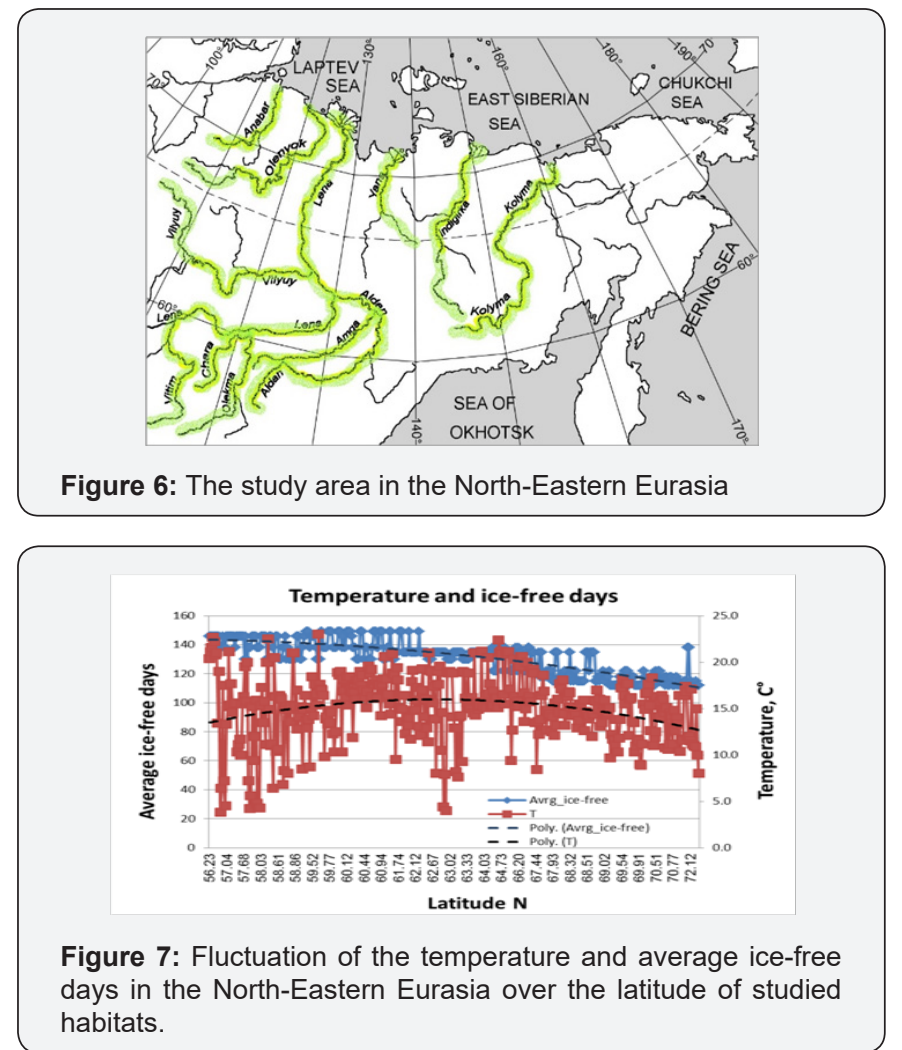

We choose the latitude of habitat as the regulated variable (Axis $\mathrm{x}$ ) for the analysis of the algal community response to global factors. Hydrobiological data was sorted over habitat latitude of each river and included phytoplankton species richness, abundance and biomass as total and over taxonomic Divisions. Below are placed the results of calculation in the graphs and histograms. The rivers are in order of its average latitude decreasing (Figure 6). The Anabar River is the northernmost of the studied rivers. We can see that abundance and biomass of phytoplankton decreased synchronous to the north (Figure 8). Species richness is usually represented by cyanobacteria, diatoms and green algae but in high Arctic it changes with the Chrysophyta algae. This trend is more pronounced in the dynamics of abundance and biomass.

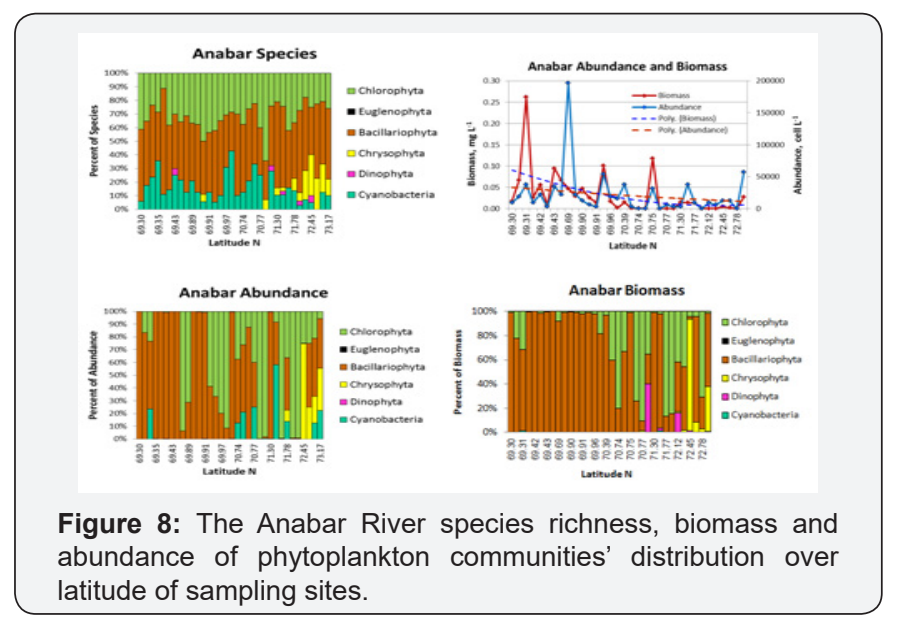

In the next, the Olenyok River, phytoplankton abundance and biomass are increased (Figure 9) but Divisional distribution of species richness, abundance and biomass are similar to it in the Anabar. In the Yana River (Figure 10) can be seen similar tendency to Olenyok. So, in Figures 8-14 we can see similar type of distribution the main feature of it is the replacing of diatom algae with greens and cyanobacteria, rarely with chrysophytic algae also. This refers to rivers above 62 degrees of northern latitude: the rivers Anabar, Olenyok, Yana, Indigirka, Kolyma, Lena, and Viluy. This type of trend is changed below the 62 degree of latitude north. The diatom prevalence with latitude shows in Figures 15-19 mostly in biomass changes histogram than in species richness.

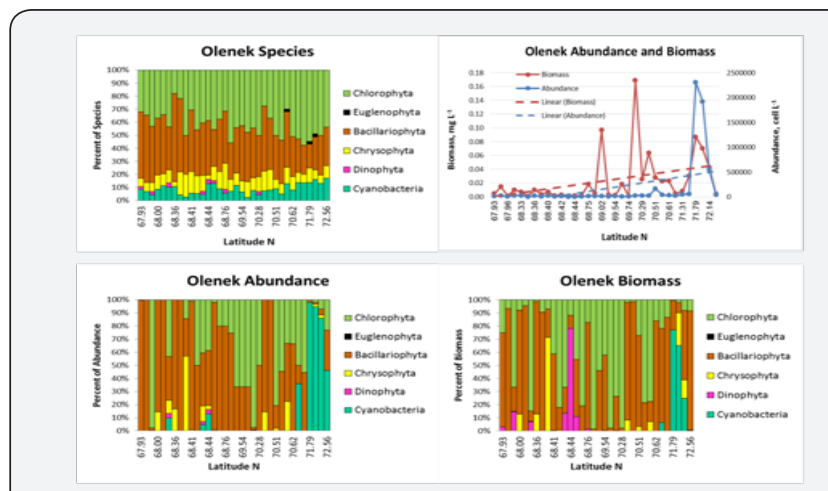

Figure 9: The Olenyok River species richness, biomass and abundance of phytoplankton communities' distribution over latitude of sampling sites.
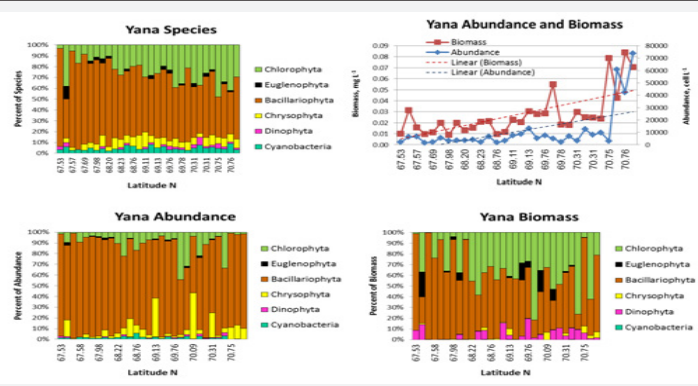

Figure 10: The Yana River species richness, biomass and abundance of phytoplankton communities' distribution over latitude of sampling sites.

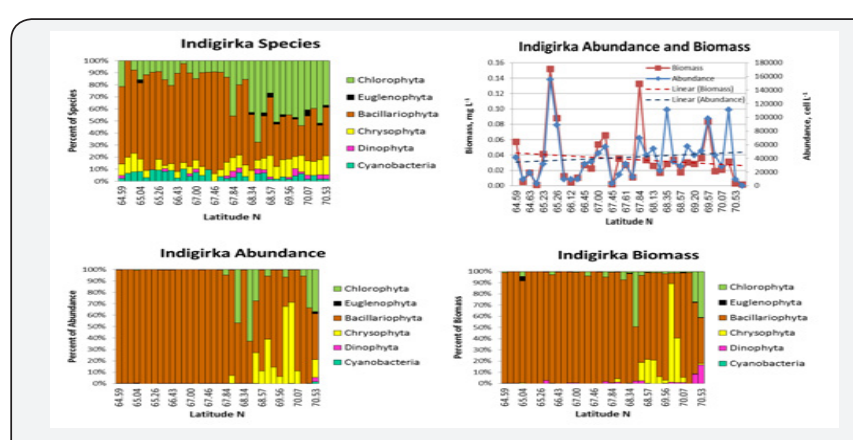

Figure 11: The Indigirka River species richness, biomass and abundance of phytoplankton communities' distribution over latitude of sampling sites. 

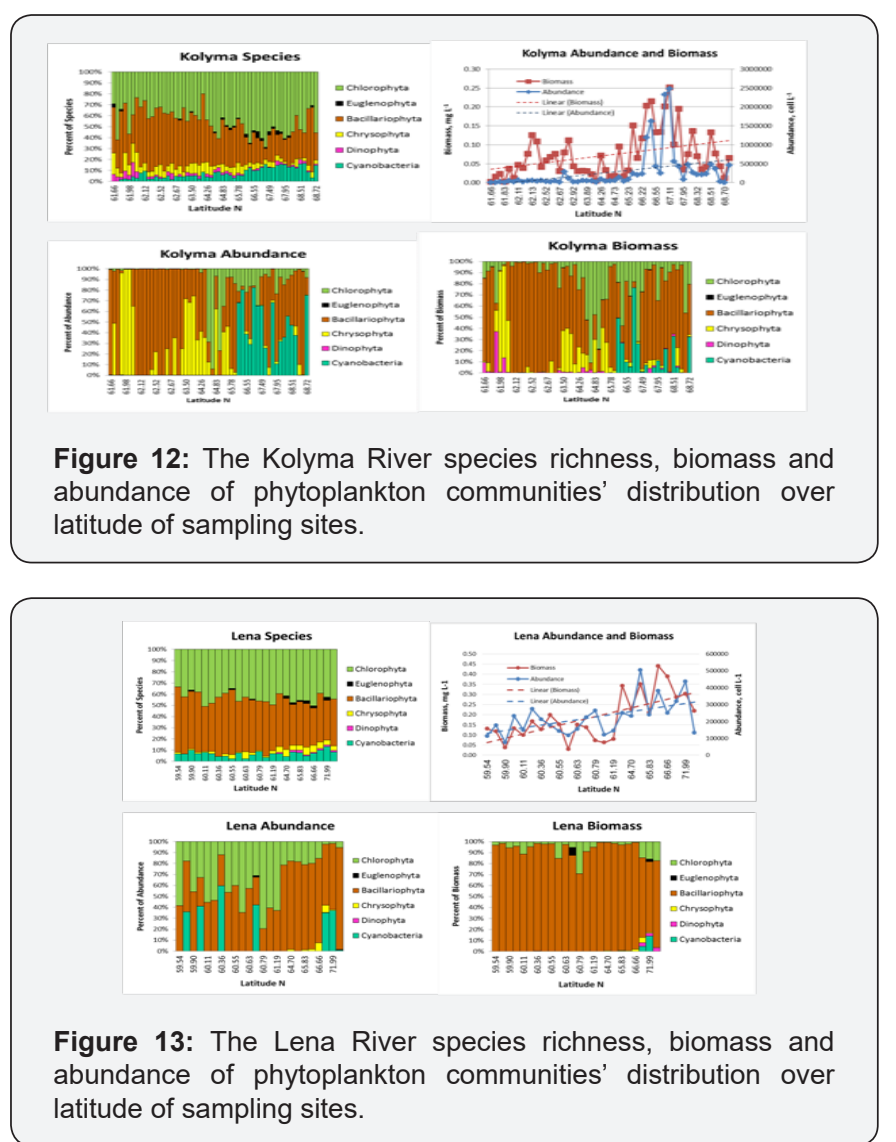

abundance of phytoplankton communities' distribution over latitude of sampling sites.

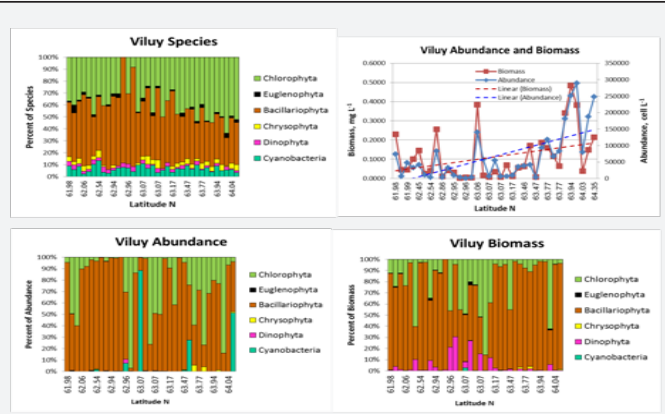

Figure 14: The Viluy River species richness, biomass and abundance of phytoplankton communities' distribution over latitude of sampling sites.

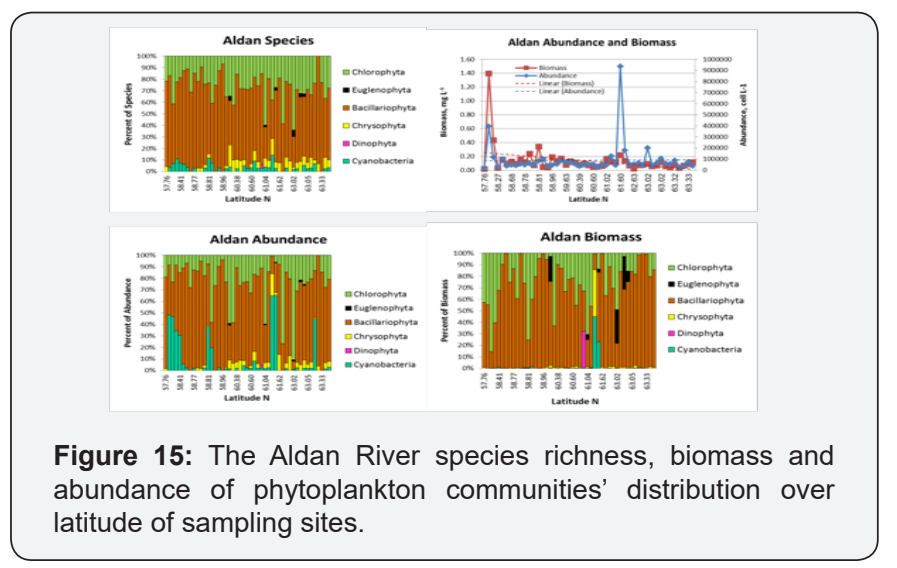

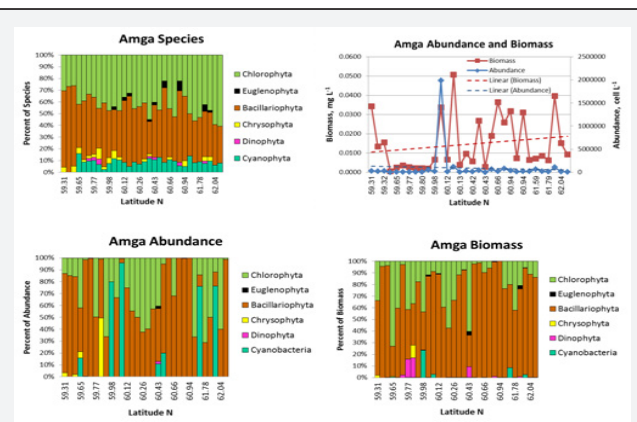

Figure 16: The Amga River species richness, biomass and abundance of phytoplankton communities' distribution over latitude of sampling sites.

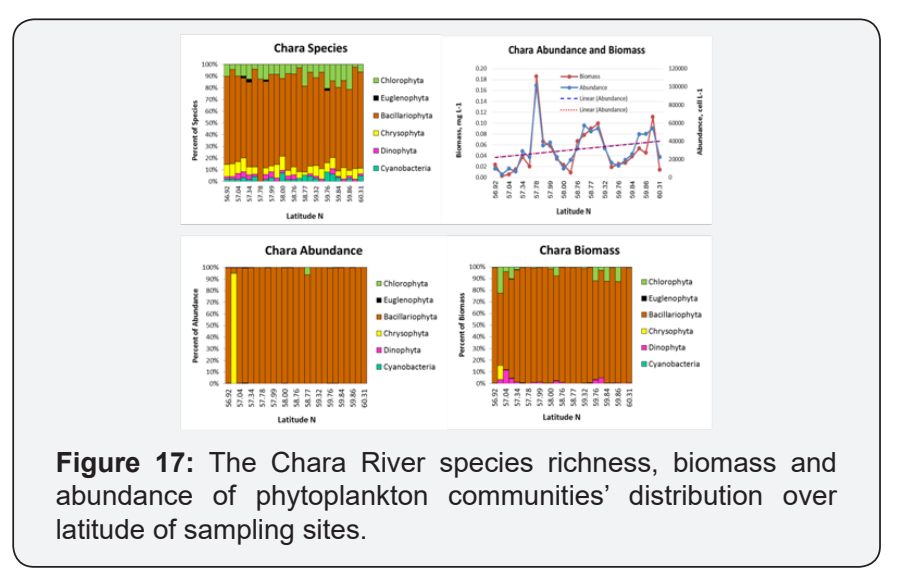

abundance of phytoplankton communities' distribution over latitude of sampling sites.
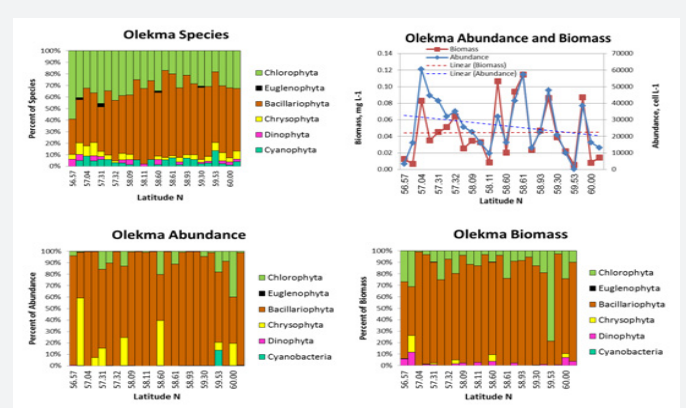

Figure 18: The Chara River species richness, biomass and abundance of phytoplankton communities' distribution over latitude of sampling sites. 


\section{Conclusion}

The study results let us to conclude that global parameters of annual solar irradiation about $1100 \mathrm{kWh} \mathrm{m}^{2}$ is critical energy for diatom active development (Figure 1). Our research reveals correlation of the El Niño in Pacific and the Far East reservoirs bloom, mostly with planktonic cyanobacteria. The northeastern rivers research let us to assume that the annual air temperature lower than $-12 \mathrm{C}^{\circ}$ is stress factor for the algal community (Figure 2). This study area is represented by most sharp climatic parameters such as minimal temperature in the World: in Verkhoyansk is pole of cold. The phytoplankton structure was changed in parallel with the incoming solar energy, as we show earlier in algal indication of climatic gradients [14]. The latitude border about 62 degree of northern latitude is also critical to the photosynthetic terrestrial plants which are changed their structure from Arctic to Temperate Forest Biomes (Figure 3). Therefore, the large scale algal diversity analysis - the gammadiversity, help us to reveal the critical level of major global climatic factors such as temperature and solar radiation for the algal species content and productivity. In high latitude habitats are survive mostly cyanobacteria and chrysophytes with majority of the green algae. It let us to conclude that climatically related variables - temperature and solar energy play a determining role in the development of algae in the continental water bodies of Eurasia. Thus, the composition and abundance of phytoplankton can serve as an indicator of climatic changes in the analysis of gamma diversity.

\section{Acknowledgement}

We are grateful to Professor V. Krassilov for guidance in the use of data on El Niño, and Dr. V. Gabyshev for providing data on phytoplankton. This work has been partly supported by the Israeli Ministry of Absorption.

\section{References}

1. Barinova S (2017) On the Classification of Water Quality from an Ecological Point of View. Int J Environ Sci Nat Res 2(2): 1-8.

2. Krassilov VA, Barinova S, Rybnikov S (2014) Rotation forcing of tectonics and climate. Earth Science, 3(3): 68-75.

3. http://www.creativhandz.co.za/images/solar_radiation.jpg.

4. https://nelson.wisc.edu/sage/data-and-models/atlas/maps/avganntemp/atl_avganntemp.jpg.

5. http://media.maps101.com/SUB/earth_science/B_World_biome.gif.

6. Morice CP, Kennedy JJ, Rayner NA, Jones PD (2012) Quantifying uncertainties in global and regional temperature change using an ensemble of observational estimates: The HadCRUT4 dataset. J Geophys Res 117(D8).

7. Barinova SS (1989) Analysis of algoflora in Artemovsk Reservoir (Primorskiy Region). Cryptogamic studies in Far East. Vladivostok: Russian Academy of Science, Far East Branch Press, Russia, p. 29-44.

8. El Nińo/Southern Oscillation (ENSO) diagnostic discussion issued by Climate Prediction Center/NCEP and the International Research Institute for climate and society.

9. http://ggweather.com/enso/oni.htm.

10. Krassilov V, Barinova S (2013) Sea level - geomagnetic polarity correlation as consequence of rotation geodynamics. Earth Science 2(1): $1-8$.

11. Snedden JW, Liu CA (2010) A compilation of Phanerozoic sea-level change, coastal onlaps and recommended sequence designations. Search and Discovery Article 40594. ExxonMobil Production Deutschland GmbH.

12. Ogg JG, Ogg G, Gradstein FM (2008) Concise Geologic Time Scale. Cambridge University Press, UK.

13. Barinova S, Gabyshev V, Gabysheva $O$ (2014) Climate impact of freshwater biodiversity: general patterns in extreme environments of North-Eastern Siberia (Russia). British Journal of Environment and Climate Change 4(4): 423-443.

14. Barinova S, Gabyshev V, Boboev M, Kukhaleishvili L, Bilous O (2015) Algal Indication of Climatic Gradients. American Journal of Environmental Protection. Special Issue: Applied Ecology: Problems, Innovations 4(3-1): 72-77.

\section{Your next submission with Juniper Publishers will reach you the below assets}

- Quality Editorial service

- Swift Peer Review

- Reprints availability

- E-prints Service

- Manuscript Podcast for convenient understanding

- Global attainment for your research

- Manuscript accessibility in different formats ( Pdf, E-pub, Full Text, Audio)

- Unceasing customer service

Track the below URL for one-step submission https://juniperpublishers.com/online-submission.php 